Gonzalez, J. M., Arquero, J. L., \& Hassall, T. (2009). Pressures and resistance to the introduction of skills in business administration and accounting education in Spain: a new institutional theory analysis. Journal of Vocational Education and Training, 61(1), 85-102.

Final paper available at http://www.tandfonline.com/doi/abs/10.1080/13636820902820071\#.VmfzkF5gvNI

\title{
Pressures and resistance to the introduction of skills in business administration and accounting education in Spain: a new institutional theory analysis
}

\author{
José María González González ${ }^{\mathrm{a}}$, José Luis Arquero Montaño ${ }^{\mathrm{a}}$, Trevor Hassall ${ }^{\mathrm{b}}$ \\ ${ }^{a}$ Department of Accounting and Finance, University of Seville, Seville, Spain; ${ }^{b}$ Faculty of \\ Organisation and Management, Sheffield Hallam University, Sheffield, United Kingdom
}

Published at Journal of Vocational Education and Training, 61(1), 85-102.

Final paper available at

http://www.tandfonline.com/doi/abs/10.1080/13636820902820071\#.VmfzkF5gvNI

Address for correspondence:

Dr. José Luis Arquero Montaño

Departamento de Contabilidad y Economía Financiera

Universidad de Sevilla

Avda. Ramón y Cajal, 1

41018 - Sevilla (España)

Email: arquero@us.es

Abstract:

Teachers, students and professionals have confirmed the need to introduce skills into business administration and accounting education in Spain. However, this change has not taken place at any desirable level. This paper uses the New Institutional Sociology (NIS) to analyse the pressures to introduce the policy that consists of the incorporation of skills in business administration and accounting education in Spain, the strategic response adopted by Spanish universities and the institutional characteristics which have determined that response. To achieve that objective, the study uses multiple sources including interviews, questionnaires, observation, informal discussions and documents. The paper evidences that the strategy developed by Spanish universities has been the "avoidance" of pressures to change. Nevertheless, due to the evolution of some institutional characteristics, the strategy has become a "compromise" strategy in the second part of the decade. The NIS is also suitable to develop future research about the changes caused by the implementation of the European Higher Education Area in most countries of the European Union.

Keywords: Business administration and accounting education; skills; resistance to change; institutional theory. 
Gonzalez, J. M., Arquero, J. L., \& Hassall, T. (2009). Pressures and resistance to the introduction of skills in business administration and accounting education in Spain: a new institutional theory analysis. Journal of Vocational Education and Training, 61(1), 85-102.

Final paper available at http://www.tandfonline.com/doi/abs/10.1080/13636820902820071\#.VmfzkF5gvNI

\section{Introduction}

In the last two decades the debate in accounting education has been highly focused in the accounting education change paradigm. From the first USA statements, Bedford report (American Accounting Association, 1986), Education requirements for entry into the accounting profession (American Institute of Certified Public Accountants, 1988) or Perspectives on education (Arthur Andersen \& Co., 1989) to the last issues of the International Federation of Accountants (IFAC) accounting education guidelines (IFAC, 2003 and 2006); relevant accounting organisations encourage a move towards a broader education. These opinions were also supported by research results (see Hassall et al., 2005 for results and literature review). This broadening should introduce, with an increased weighting, general knowledge and the development of non technical skills into the accounting curriculum. Therefore, teachers should be charged with the development, not only of accounting content, but also of intellectual, interpersonal and personal skills.

In Spain, in particular, Arquero (2000) developed an extensive study which aimed to identify the non technical skills suggested by teachers and required by employers for the business administration and accounting curriculum ${ }^{1}$. Arquero (2000) highlighted the need for incorporating into the curriculum autonomous learning, information analysis and synthesis, oral communication, teamwork, leadership, time and task planning and languages.

However, further research has highlighted that the educational expectation gap still existed after several years in many countries generally (Albretch and Sack, 2000) and in Spain in particular (Arquero et al., 2005; González et al., 2006). Therefore, if there is an agreement by the stakeholders concerning the need for a change, and that change has not occurred, the reasons for this reluctance to change should be identified and studied in depth. The literature

\footnotetext{
${ }^{1}$ Unlike most European countries, there is no specific degree in accounting in Spain. This issue is discussed in the fourth section.
} 
Gonzalez, J. M., Arquero, J. L., \& Hassall, T. (2009). Pressures and resistance to the introduction of skills in business administration and accounting education in Spain: a new institutional theory analysis. Journal of Vocational Education and Training, 61(1), 85-102.

Final paper available at http://www.tandfonline.com/doi/abs/10.1080/13636820902820071\#.VmfzkF5gvNI

attempting to explain the barriers to, or the pressures preventing, the required change is scarce and in overall terms, does not present a clear theoretical framework. The present paper aims to investigate the pressures and resistance to introduce the policy that consists of the incorporation of skills in business administration and accounting education in Spain, adopting an institutional theory approach and using several sources of information (interviews, questionnaires, observation and informal discussions).

The New Institutional Sociology (NIS) is one of the most dominant perspectives in organisational analysis (Lounsbury, 2008). This theory is useful for analysing and understanding change in organisational fields (Dacin et al., 2002) and specifically, for analysing organisations that are confronted with uncertainties and as a result compete for political and institutional legitimacy and market position (DiMaggio and Powell, 1983). In education research, in particular, the NIS also has had an important impact. In this sense, as Meyer and Rowan (2006, p. 4) noted, "through institutional analysis we learn something about how education connects with other vital institutions in society; what the constraints are under which this important part of our social life takes place; and what the latitude and the limits are that we confront if we attempted to change the existing institutional order". In this paper, in particular, the NIS allows us to analyse the pressures of the organisational and institutional context of Spanish universities for introducing skills in education plans as well as the response to them to those pressures which are in turn influenced and limited by their organisational and institutional context.

The rest of the paper is structured as follows: the second section presents the NIS as our theoretical framework. The third section is devoted to the research method. A background of the Spanish business administration and accounting education is presented in the fourth section. The fifth, sixth and seventh sections present and analyse, respectively, the results of 
Gonzalez, J. M., Arquero, J. L., \& Hassall, T. (2009). Pressures and resistance to the introduction of skills in business administration and accounting education in Spain: a new institutional theory analysis. Journal of Vocational Education and Training, 61(1), 85-102.

Final paper available at http://www.tandfonline.com/doi/abs/10.1080/13636820902820071\#.VmfzkF5gvNI

the study about the pressures to change, the strategic response of Spanish universities and the institutional antecedents of that response. Finally, the conclusions, implications and suggestions for further research are presented.

\section{Theoretical framework: the new institutional sociology}

NIS focuses on the symbolic aspect as well as the wider environment of organisations (Scott and Meyer, 1994; Scott, 2001). According to this theory, being technically efficient does not assure organisations of their survival (Meyer and Rowan, 1977). On the contrary, organisations also need to conform to the rules, norms and values of their institutional environment to obtain both legitimacy and resources that they need to survive (Meyer and Rowan, 1977; Meyer, 1986; Carruthers, 1995; Deephouse and Suchman, 2008). The defenders of new institutionalism argue that organisations which share the same environment are subject to the same institutional pressures and as a result they tend to be isomorphic in their structures and the behaviours they employ to obtain legitimacy (DiMaggio and Powell, 1983 and 1991; Mizruchi and Fein, 1999; Boxenbaum and Jonsson, 2008).

\section{Competitive and institutional isomorphic pressures to change}

DiMaggio and Powell (1983) identified two broad types of pressures for isomorphic change in organisations: competitive and institutional. In competitive situations, organisations become increasingly similar to the extent that rules of behaviour enable exchange processes to be undertaken efficiently (Etherington and Richardson, 1994). Thus, competitive isomorphism is related to the search for efficiency, and it is more relevant for those situations in which free and open competition exists. 
Gonzalez, J. M., Arquero, J. L., \& Hassall, T. (2009). Pressures and resistance to the introduction of skills in business administration and accounting education in Spain: a new institutional theory analysis. Journal of Vocational Education and Training, 61(1), 85-102.

Final paper available at http://www.tandfonline.com/doi/abs/10.1080/13636820902820071\#.VmfzkF5gvNI

However, isomorphism can be expected to proceed irrespective of its contribution to the improvement of the organisational efficiency since organisations are rewarded for their similarity to other organisations in their fields. Therefore, isomorphism also contributes to the maintenance of organisational power and institutional legitimacy (Deephouse, 1996; Deephouse and Suchman, 2008).

DiMaggio and Powell (1983) subdivided the institutional pressures for isomorphic change into categories of coercive, mimetic, and normative. Coercive isomorphic pressures occur because organisations are seen as depending on the external environment for resources to survive (Pfeffer and Salancik, 1978; Pfeffer, 1981; Oliver, 1991). This suggests that successful organisations are those that are able to negotiate with the external environment for resources (Dacin, 1997; Carpenter and Feroz, 2001). Coercive isomorphism occurs due to pressures from external resource providers including the state and the credit markets and from the pressure on an organisation to conform to the cultural expectations of the larger society. According to DiMaggio and Powell (1983, p.152), mimetic isomorphic pressures mean that "organisations tend to model themselves after similar organisations in their field that they perceive to be more legitimate or successful". Thus organisations operating under conditions of uncertainty will tend to imitate other organisations that they consider successful. Thus "mimetic isomorphism is a response to an organisational uncertainty in identifying the best course of action" (Carpenter and Feroz, 2001, p. 571).

Finally normative isomorphic pressures for change are associated with professionalisation and occur when organisations seek institutional legitimacy (Meyer and Scott, 1982; DiMaggio and Powell, 1983; Scott, 2001). Organisations may find it easier to legitimize their activities when such practices are culturally supported. As argued by Meyer and Scott (1982) such cultural support can come from professional associations both local and worldwide. DiMaggio and 
Gonzalez, J. M., Arquero, J. L., \& Hassall, T. (2009). Pressures and resistance to the introduction of skills in business administration and accounting education in Spain: a new institutional theory analysis. Journal of Vocational Education and Training, 61(1), 85-102.

Final paper available at http://www.tandfonline.com/doi/abs/10.1080/13636820902820071\#.VmfzkF5gvNI

Powell (1983) suggested that professionalisation has an important role in this type of isomorphism since it embraces two aspects that generate isomorphism: the growth of professional networks that span organisations; and formal education produced by university specialists and by professional training institutions.

\section{Responses to isomorphic pressures and their institutional antecedents}

The earlier formulation of NIS has been criticized for its focus on the isomorphism and the symbolic conformity with minimal attention to the roles of other factors such us interests, agency, conflict, power and change process (Scott, 2001). In this sense, Oliver's (1991) work has constituted an important contribution for NIS (Lounsbury, 2008; Boxenbaum and Jonsson, 2008) and it has been used as the theoretical framework in several works about education research (e.g. Etherington and Richardson, 1994; Asonitou and Hassall, 2008) because it suggests that organisations do not always bind mimic or acquiesce in the face of institutional pressures, but they can adopt various different strategic responses. Specifically, Oliver (1991) identified five types of responses of organisational conformity or resistance to those pressures (Table 1).

Table 1. Strategic responses to pressures to change

\begin{tabular}{|l|l|l|}
\hline Response & Brief description & Classification \\
\hline Defy & $\begin{array}{l}\text { Organizations deal with pressures through direct } \\
\text { confrontation }\end{array}$ & Active/negative \\
\hline Avoid & $\begin{array}{l}\text { Organizations try to preclude the necessity of conformity } \\
\text { without affecting the nature of pressures }\end{array}$ & Active/negative \\
\hline Acquiesce & $\begin{array}{l}\text { Organizations accede to pressures without significant } \\
\text { alteration }\end{array}$ & Passive/neutral \\
\hline Compromise & $\begin{array}{l}\text { Organizations negotiate a balance between their interests } \\
\text { and the interests of institutions }\end{array}$ & Active/positive \\
\hline Manipulate & $\begin{array}{l}\text { Organizations try to redirect pressures to their own } \\
\text { advantage }\end{array}$ & Active/positive \\
\hline
\end{tabular}

Source: Oliver (1991) and Etherington and Richardson (1994). 
Gonzalez, J. M., Arquero, J. L., \& Hassall, T. (2009). Pressures and resistance to the introduction of skills in business administration and accounting education in Spain: a new institutional theory analysis. Journal of Vocational Education and Training, 61(1), 85-102.

Final paper available at http://www.tandfonline.com/doi/abs/10.1080/13636820902820071\#.VmfzkF5gvNI

According to Etherington and Richardson (1994), those responses can be ordered in turn as a continuum based on two dimensions: passive/active responses and positive/negative responses. The responses "defy" and "avoid" are active because they result in behaviours that differ from those demanded by pressures of the environment; and negative because they maintain conflict between the behaviour of organisations and requirements of organisational environment. The responses "compromise" and "manipulate" are also active but they are positive because they intend to achieve the adaptation between the behaviour of organisations and requirements of organisational environment. Conversely the response "acquiesce" is passive and neutral because entails the acceptance by organisations of demands of organisational environment. Therefore, resistance to change is "the adoption of an active (positive or negative) strategy in response to institutional pressures" (Etherington and Richardson, 1994, p. 145).

Oliver (1991) argued also that the characteristics of institutional pressures which are also called "institutional antecedents" can explain the choice of one strategy over another by organisations. Specifically, Oliver (1991) considered ten institutional characteristics or antecedents which are related to the cause, constituents, content, control and context of institutional pressures (Table 2).

In this paper, Oliver's (1991) framework provides the conceptual categories for analysing the change in business administration and accounting education in Spain. Firstly, we analyse the institutional and competitive pressures to introduce the policy which aims to incorporate skills in the education plan of that degree. Secondly, we analyse the strategy adopted by Spanish universities to respond to those pressures. Finally, we examine the institutional antecedents 
Gonzalez, J. M., Arquero, J. L., \& Hassall, T. (2009). Pressures and resistance to the introduction of skills in business administration and accounting education in Spain: a new institutional theory analysis. Journal of Vocational Education and Training, 61(1), 85-102.

Final paper available at http://www.tandfonline.com/doi/abs/10.1080/13636820902820071\#.VmfzkF5gvNI

which led to the choice of that strategic response of Spanish universities. This is summarized in Figure 1.

Table 2. Antecedents of strategic responses

\begin{tabular}{|c|c|c|}
\hline Factor & Question & Antecedent \\
\hline \multirow{2}{*}{ Cause } & \multirow{2}{*}{$\begin{array}{l}\text { Why is the } \\
\text { organisation being } \\
\text { pressured to } \\
\text { conform to } \\
\text { institutional rules } \\
\text { or expectations? }\end{array}$} & $\begin{array}{l}\text { Efficiency: The degree to which the changes are } \\
\text { necessary to maintain the economic fitness (efficiency) } \\
\text { of the organisation }\end{array}$ \\
\hline & & $\begin{array}{l}\text { Legitimacy: The degree to which the changes are } \\
\text { necessary to maintain the social fitness (legitimacy) of } \\
\text { the organisation }\end{array}$ \\
\hline \multirow{2}{*}{ Constituents } & \multirow{2}{*}{$\begin{array}{l}\text { Who is exerting } \\
\text { institutional } \\
\text { pressures on the } \\
\text { organisation? }\end{array}$} & $\begin{array}{l}\text { Multiplicity: The degree of consensus in demands being } \\
\text { made on the organisation }\end{array}$ \\
\hline & & $\begin{array}{l}\text { Resource dependence: The degree of dependence of the } \\
\text { organisation on the actor exerting pressure for change }\end{array}$ \\
\hline \multirow[t]{2}{*}{ Content } & \multirow{2}{*}{$\begin{array}{l}\text { To what norms or } \\
\text { requirements is the } \\
\text { organisation being } \\
\text { pressured to } \\
\text { conform? }\end{array}$} & $\begin{array}{l}\text { Goal congruence: The degree of consistency between } \\
\text { the faculty and university goals and the demands for } \\
\text { change }\end{array}$ \\
\hline & & $\begin{array}{l}\text { Reduced discretion: The degree to which discretion is } \\
\text { constrained by compliance with external demands }\end{array}$ \\
\hline \multirow[b]{2}{*}{ Control } & \multirow{2}{*}{$\begin{array}{l}\text { How or by what } \\
\text { means are the } \\
\text { institutional } \\
\text { pressures being } \\
\text { exerted? }\end{array}$} & $\begin{array}{l}\text { Coercion: The degree of legal coercion associated with } \\
\text { the demands for change }\end{array}$ \\
\hline & & $\begin{array}{l}\text { Diffusion: The degree of voluntary diffusion of } \\
\text { innovations }\end{array}$ \\
\hline \multirow[b]{2}{*}{ Context } & \multirow{2}{*}{$\begin{array}{l}\text { What is the } \\
\text { environmental } \\
\text { context within } \\
\text { which institutional } \\
\text { pressures are being } \\
\text { exerted? }\end{array}$} & $\begin{array}{l}\text { Interconnectedness: The degree of interconnectedness of } \\
\text { actors pressing for change }\end{array}$ \\
\hline & & $\begin{array}{l}\text { Uncertainty: The degree of uncertainty of the } \\
\text { appropriate change and of the consequences of lack of } \\
\text { change }\end{array}$ \\
\hline
\end{tabular}

Source: Oliver (1991) and Etherington and Richardson (1994). 
Gonzalez, J. M., Arquero, J. L., \& Hassall, T. (2009). Pressures and resistance to the introduction of skills in business administration and accounting education in Spain: a new institutional theory analysis. Journal of Vocational Education and Training, 61(1), 85-102.

Final paper available at http://www.tandfonline.com/doi/abs/10.1080/13636820902820071\#.VmfzkF5gvNI

Figure 1. Pressures and strategic response to change in education in Spain
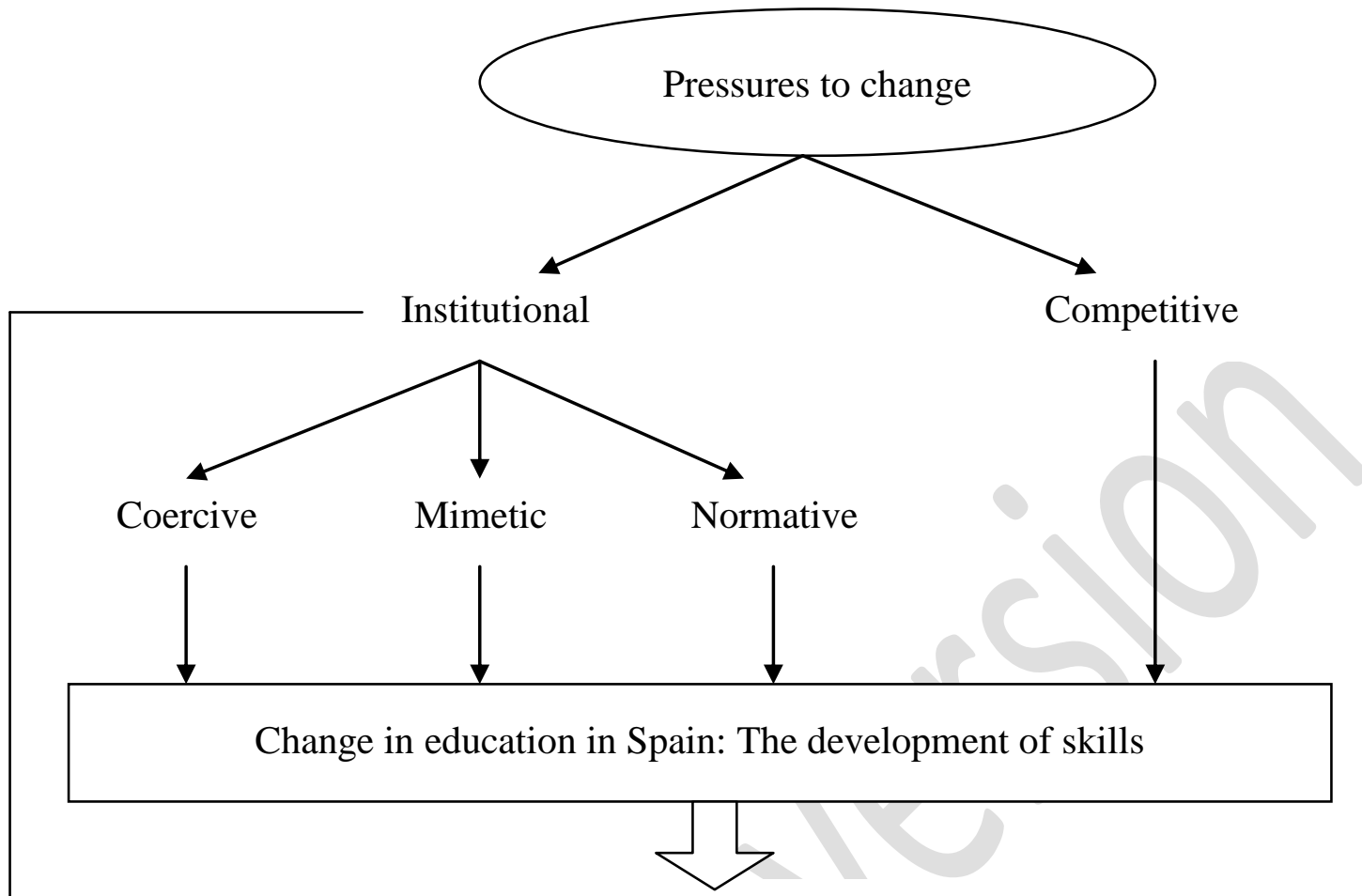

Potential strategic responses of Spanish universities

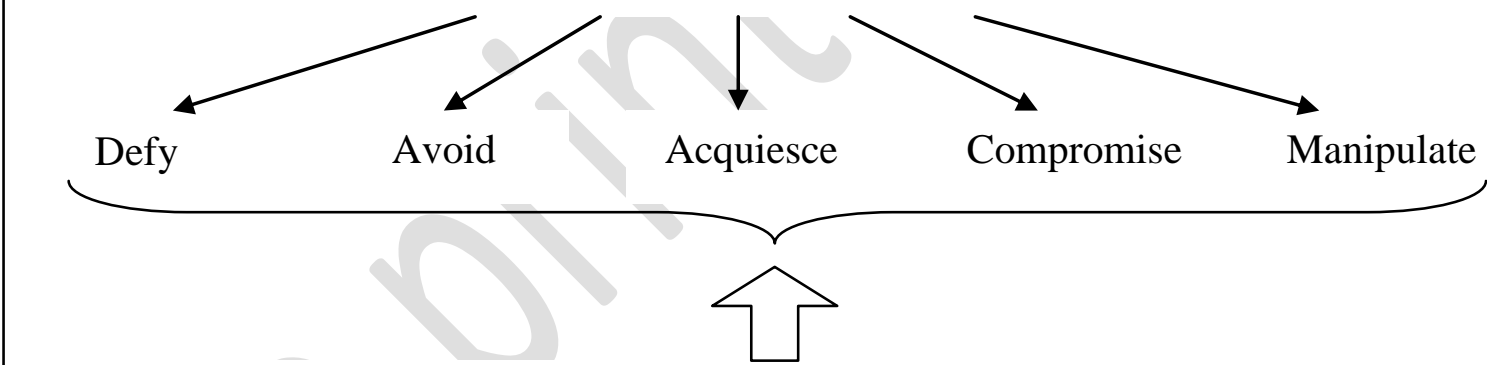

Institutional characteristics or antecedents of pressures that have determined the choice of the strategic response

\section{Research method}

The research period extended from the academic year 2000/2001 to the academic year 2005/2006. In order to collect evidence this study used the following sources: data from questionnaires, semi-structured interviews, observation, analysis of documents and informal discussions. Data from more than 1.300 questionnaires were available. The questionnaires were developed for a concurrent research project on educational 
Gonzalez, J. M., Arquero, J. L., \& Hassall, T. (2009). Pressures and resistance to the introduction of skills in business administration and accounting education in Spain: a new institutional theory analysis. Journal of Vocational Education and Training, 61(1), 85-102.

Final paper available at http://www.tandfonline.com/doi/abs/10.1080/13636820902820071\#.VmfzkF5gvNI

needs focused on vocational skills (Arquero, 2000; Arquero and Donoso, 2002; Hassall et al., 2005). From those pieces of research relevant information was obtained for the present paper. The questionnaires were completed by Spanish university students of Licenciado in Management and Business Administration and Diplomado in Business Studies, accounting professionals and business administration and accounting university teachers. These questionnaires provided significant information about the importance of the development of students' skills in the curriculum as well as the limitations and constraints for the development of students' skills in Spanish universities. Specifically the answers of students and professionals were very important in order to understand the institutional and competitive pressures for the change (the introduction of skills in business administration and accounting education), whereas the answers of teachers were mainly taken into account for analyzing the strategic response of Spanish universities to the pressures for change.

Semi-structured interviews were carried out with twenty one Spanish business administration and accounting teachers and eight accounting professionals. The duration of the interviews varied from one hour and twenty minutes the shorter interview to two hours and five minutes the longer interview. Thirteen of the teachers were civil servants (tenured staff) and eight were labour teachers (untenured). Some of these were senior teachers and others were newer teachers in Spanish universities. The questions used in the interviews of teachers were classified into three sections: pressures for changing education, in particular, for introducing skills in the student's learning; repercussions on business administration and accounting education; and repercussions on business administration and accounting educators and their reactions and behaviours. These interviews provided us with relevant information about the institutional antecedents of the strategic response of Spanish universities, as well as the 
Gonzalez, J. M., Arquero, J. L., \& Hassall, T. (2009). Pressures and resistance to the introduction of skills in business administration and accounting education in Spain: a new institutional theory analysis. Journal of Vocational Education and Training, 61(1), 85-102.

Final paper available at http://www.tandfonline.com/doi/abs/10.1080/13636820902820071\#.VmfzkF5gvNI

repercussions on business administration and accounting education. On the other hand, among the professionals that were interviewed, there were financial controllers and individuals who had developed their careers in consulting and auditing firms. Because of the big experience of these professionals in their jobs it was possible to capture a wide view of the accounting profession in Spain. The questions used in the interviews of professionals were classified into three sections: professional experience; knowledge and skills required to the future professionals; limitations to the learning of students. The interviews of professionals provided us with relevant information to obtain a sound knowledge of the pressures and limitations to change.

The analysed documents were used to contextualize the pressures to change and the response by Spanish universities. Specific documents highlighted include, the regulation of the Spanish university system, the education plans for the recognition of Licenciado in Management and Business Administration and Diplomado in Business Studies, and the internal reports prepared by some universities about the learning methods of students. The paper establishes a wide description of the Spanish university system through the direct and systematic observation of the authors. Specifically, at the beginning of the research, the authors established the following aspects in order to be observed during the research period: pressures of the environment on teachers and their teaching activities, constraints identified by teachers that affect the attaining of educational objectives and behaviours and responses adopted by teachers to face the pressures and to overcome the limitations. Finally, throughout the research period fifteen informal discussions were scheduled with business administration and accounting teachers of several Spanish universities and also various accounting professionals in order to compare the information collected through the other formal sources. 
Gonzalez, J. M., Arquero, J. L., \& Hassall, T. (2009). Pressures and resistance to the introduction of skills in business administration and accounting education in Spain: a new institutional theory analysis. Journal of Vocational Education and Training, 61(1), 85-102.

Final paper available at http://www.tandfonline.com/doi/abs/10.1080/13636820902820071\#.VmfzkF5gvNI

The use of multiple sources for collecting evidence allowed us the data triangulation and therefore to enhance the validity of the results. The data triangulation approach adopted was particularly useful, as it enabled us to obtain a contextual portrayal of the social phenomena under study. However, it also created challenges in terms of analysing and making sense of data collected from these various sources. To overcome this problem, we started our analysis by collecting from the questionnaires information about the perceived importance of skills in the learning of students as well as the pressures and limitations to introduce them in education plans. The interviews allowed us to go deeply into the pressures and limitations to change and also to expand on the information about the strategic response of universities to change and their antecedents. The information from documentary evidence and observations were subsequently matched with the main themes of our study: pressures, strategic response and antecedents. The informal discussions were used to clarify some aspects of the collected evidence previously. In the last part of the analysis, we drew on NIS, mainly Oliver's (1991) framework, to make sense of the data. Subsequently, we discussed the preliminary results of the research with some key informants (teachers and professionals) in order to go deeply into some details of our interpretations and results.

\section{The Spanish business administration and accounting education background}

Traditionally in Spain the higher education is structured in three cycles through which students can obtain degrees: Diplomado, for students that have completed three years study concerning basic knowledge and general training; Licenciado $^{2}$, which is conferred after five years study and is concerned with a more specialized education; and Doctor whose main purpose is to educate students about research techniques and skills in a specific knowledge

\footnotetext{
${ }^{2}$ Students awarded with a Diplomado degree can continue their studies to get a Licenciado degree in the same speciality by coursing two additional years.
} 
Gonzalez, J. M., Arquero, J. L., \& Hassall, T. (2009). Pressures and resistance to the introduction of skills in business administration and accounting education in Spain: a new institutional theory analysis. Journal of Vocational Education and Training, 61(1), 85-102.

Final paper available at http://www.tandfonline.com/doi/abs/10.1080/13636820902820071\#.VmfzkF5gvNI

area. In Spain there is no specific degree in accounting; accounting is a core part along with other knowledge areas in the education plans for the recognition of Licenciado in Management and Business Administration and Diplomado in Business Studies.

In the Spanish context there are two main sources of authority in the development of the curriculum of students: government and universities. The Spanish government draw up two types of general guidelines: common guidelines which are concerned with all higher education degrees (Royal Decree 1497/1987 which established the initial ${ }^{3}$ general guidelines); and specific guidelines for each individual higher education degree (e.g. Royal Decree 1421/1990 which established the initial specific guidelines for Licenciado in management business administration). Universities themselves are responsible for designing the specific curriculum for each degree by taking into account the requirements of the general guidelines. The education plans for obtaining the degrees of Licenciado in Management and Business Administration and Diplomado in Business Studies must therefore conform to the common and specific guidelines

Since the mid-1980s the Spanish university system has changed to become a massive higher education system (Mora, 1999; Mora and Vidal, 2000; Langa and David, 2006) which has conditioned the pedagogical methods. The pedagogic approach to business administration and accounting education has been mainly based on practical or theoretical lectures. Many classes are delivered to more than 100 students and therefore methods that include active participation of students are not so widespread. For this reason the assessment is mainly in three/four hours written examinations in which teachers try to assess the specific knowledge of students in business administration and accounting (see González et al., 2006).

\footnotetext{
${ }^{3}$ They are "initial" guidelines because they have been modified several times during the decades of 1990 and 2000 .
} 
Gonzalez, J. M., Arquero, J. L., \& Hassall, T. (2009). Pressures and resistance to the introduction of skills in business administration and accounting education in Spain: a new institutional theory analysis. Journal of Vocational Education and Training, 61(1), 85-102.

Final paper available at http://www.tandfonline.com/doi/abs/10.1080/13636820902820071\#.VmfzkF5gvNI

\section{Institutional and competitive isomorphic pressures}

Since the end of 1990s business administration and accounting education in Spain has faced both institutional (coercive, mimetic and normative) and competitive pressures in order to develop the skills of students who are undertaking the Licenciado in Management and Business Administration and the Diplomado in Business Studies. Next, we present and analyse those pressures.

\section{Coercive pressure}

The European Union countries signed the Bologna Declaration in 1999 which introduced an important challenge for them: the harmonization of their higher education systems through the set up of the European Higher Education Area (EHEA) which will come into effect in 2010. One strategic objective of the EHEA is the implementation of the European Credit Transfer System (ECTS) which implies the orientation of education programmes and methodologies toward the student's learning as well as the establishment of a comparable assessment system into the EHEA (Bologna Declaration 1999).

Specifically, the European credit is the unit of measurement of students' work in completing the education programme. One credit is equivalent to $25-30$ hours of students' work and it takes into account the time devoted by students to practical and theoretical lectures, study, tutorials, seminars, works, practices and examination preparation. Through the development of those tasks, students should acquire both technical knowledge and skills such as communication, teamwork, solution of conflicts, etc. (Document EHEA prepared for the Spanish Ministry of Education and Science, 2005).

Since the signing of the Bologna Declaration, Spain has begun the transformation process of the Spanish university system at the beginning of the millennium in order to adapt to the 
Gonzalez, J. M., Arquero, J. L., \& Hassall, T. (2009). Pressures and resistance to the introduction of skills in business administration and accounting education in Spain: a new institutional theory analysis. Journal of Vocational Education and Training, 61(1), 85-102.

Final paper available at http://www.tandfonline.com/doi/abs/10.1080/13636820902820071\#.VmfzkF5gvNI

requirements of the EHEA. For it, the University Organic Law 6/2001 and the Royal Decree $1125 / 2003$ concerning the implementation of the ECTS were approved in Spain. As a consequence Spanish universities have had to redesign their higher education degrees according to the new guidelines that have been set up by the government (Royal Decree 55/2005 for the official studies of Grado and Royal Decree 56/2005 for the official studies of Posgrado). For instance, for the degree in Management and Business Administration, universities have to specify the skills acquired by students for each unit of the degree, among them accounting units, and the way for acquiring those skills.

These results evidence the influence of institutional and political processes on the formation of the Spanish university system (Brignall and Modell, 2000). In particular, they reinforce the argument of the coercion of political and legal environments as a source of institutional isomorphism (DiMaggio and Powell, 1983; Dacin et al., 2002) because they are forcing the incorporation of skills in Spanish higher education. In our case, coercive pressures arise mainly from the European Union and Spanish government by means of the introduction of new regulation (DiMaggio and Powell, 1983; Mizruchi and Fein, 1999). In this sense, the Bologna Declaration was instrumental in pressuring the Spanish government to initiate the restructuring process of education plans in order to introduce skills in student's learning. According to NIS, nation-states often exercise coercive isomorphism and they impose their frameworks on higher education systems (Scott and Meyer, 1994; Scott, 2001). In Spain, the coercive isomorphism has its principal cause in the formal pressures exerted on universities by other constituents upon which they are dependent, specifically, European Union and Spanish government (Pfeffer, 1981; DiMaggio and Powell, 1991).

\section{Mimetic pressure}


Gonzalez, J. M., Arquero, J. L., \& Hassall, T. (2009). Pressures and resistance to the introduction of skills in business administration and accounting education in Spain: a new institutional theory analysis. Journal of Vocational Education and Training, 61(1), 85-102.

Final paper available at http://www.tandfonline.com/doi/abs/10.1080/13636820902820071\#.VmfzkF5gvNI

The implementation of the EHEA has caused uncertainty among Spanish universities surrounding the requirements for change in higher education degrees and in accounting education units in particular. In this respect, an interviewee noted that "the change that the Spanish university must undertake is big and complex. However, the influence of that change on the learning methods or the content of the degrees are not clear yet. Also, the transition from the traditional system to the EHEA neither is clear". The most of interviewees also noted that some European countries, such as UK, are more advanced than Spain in the implementation of the EHEA, especially as regards the introduction of skills in the student's learning. In this sense, several interviewees have carried out long stays in UK universities and all of them considered that their education philosophy is closer to the aim of the EHEA. As a consequence, they can constitute a good referent for the Spanish universities. With regard to skills in accounting education, for instance, these interviewees highlighted that, in general terms, many UK universities have adopted a more active learning approach by students. Under this approach, teachers deliver one hour lectures to large groups of students and seminars to smaller groups. In these seminars the students do exercises, case studies, cooperative learning, role plays and they may use the internet and interactive DVD's. Also the assessment system in the UK includes continuous assessment with units containing between $25 \%$ to $100 \%$ coursework. This would include objective testing, the preparation of case studies, written reports and oral presentations both individual and group. This evidence was contrasted with the results obtained by González et al. (2006).

We have been able to observe also that Spanish teachers of business administration and accounting have shown their interest in increasing their knowledge about the teaching and assessment methods used for accounting education in the UK. For instance, the Spanish Association of Accounting University Teachers (ASEPUC) have held several seminars and 
Gonzalez, J. M., Arquero, J. L., \& Hassall, T. (2009). Pressures and resistance to the introduction of skills in business administration and accounting education in Spain: a new institutional theory analysis. Journal of Vocational Education and Training, 61(1), 85-102.

Final paper available at http://www.tandfonline.com/doi/abs/10.1080/13636820902820071\#.VmfzkF5gvNI

conferences ${ }^{4}$ in which some English teachers of accounting have been invited in order to explain the acquisition of technical knowledge and skills by students of accounting education in UK.

According to the arguments of NIS, Spanish universities may decide that the best way to respond to the uncertainty in the context is to mimic universities from other countries that are perceived as more advanced in their convergence process towards the EHEA (DiMaggio and Powell, 1983; Oliver, 1991; Mizruchi and Fein, 1999). In this sense, the higher education system of UK has constituted a good referent for Spanish business administration and accounting teachers because some traditional characteristics of that system adapt to the requirements of the EHEA (González et al., 2006).

\section{Normative pressure}

Normative pressures have their origins in the influence of the expectations of society generally, and professional bodies in particular (Greenwood et al., 2002), on the practices of organisations (DiMaggio and Powell, 1983). In the context of business administration and accounting education in Spain the professional bodies have their own expectations about the appropriate content of curriculum of students. Arquero et al. (2005) reported that there is an important breach between the current content of curriculum of students in Management and Business Administration and the knowledge and skills that are regarded as necessary by practitioners in order to perform adequately in the professional area.

In the questionnaires, accounting professionals highlighted those universities when designing syllabuses should pay attention to work place requirements. They expressed the view that the development of skills and competences must be an explicit goal of university education

\footnotetext{
${ }^{4}$ For instance, the Third Seminar of Education Training for Accounting Teachers (2004) and the Fifth Conference on Accounting Education (2006).
} 
Gonzalez, J. M., Arquero, J. L., \& Hassall, T. (2009). Pressures and resistance to the introduction of skills in business administration and accounting education in Spain: a new institutional theory analysis. Journal of Vocational Education and Training, 61(1), 85-102.

Final paper available at http://www.tandfonline.com/doi/abs/10.1080/13636820902820071\#.VmfzkF5gvNI

because in personnel selection those skills are given at least the same value as accounting knowledge. As an interviewee noted, "universities should be more conscious of the opportunities that each unit offers to develop skills and competences of students in order to implement strategies that promote the learning of those skills and also to establish assessment processes of them". Also, the most of professionals who were interviewed pointed out that it is possible to develop skills simultaneously with the teaching of technical-accounting knowledge by using certain teaching methods and also the development of skills should be integrated into accounting units.

However, accounting professionals also highlighted in the questionnaires several limitations in the development of skills of students. In reducing order of importance, the first three limitations pointed out by professionals are the following ones: (1) the large class sizes in Spanish universities for the degrees in Management and Business Administration and Business Studies, (2) the lack of practical experience of educators and their lack of contact with the business reality, and (3) the lack of training of educators about the development of skills. Other limitations were also noted by professionals through the interviews. In particular, they emphasized that universities are not sufficiently active in collaborating with business organisations. They also perceive a lack of permanent communication with small and medium organisations in order to gain knowledge of their needs.

\section{Competitive pressure}

With respect to the university system of United Kingdom, Gammie and Gammie (2002, p. 5) noted that "academic knowledge in the higher education sector has been reorganised along a utilitarian trajectory such that, at the macro level, the dominant legitimating idea of public higher education has changed from that of a social institution to that of an industry". This 
Gonzalez, J. M., Arquero, J. L., \& Hassall, T. (2009). Pressures and resistance to the introduction of skills in business administration and accounting education in Spain: a new institutional theory analysis. Journal of Vocational Education and Training, 61(1), 85-102.

Final paper available at http://www.tandfonline.com/doi/abs/10.1080/13636820902820071\#.VmfzkF5gvNI

trend is taking place in Spain and the EHEA is speeding it up (González et al., 2006). As a consequence the new environment for the Spanish universities is becoming more competitive. For instance the National Agency of Assessment of the University Quality and Accreditation (ANECA), which was constituted in 2002, is responsible for assessing and verifying the education plans as well as services and management activities carried out by Spanish universities (University Organic Law 6/2001). These assessments may condition the decision of students concerning the university in which they wish to study. In all probability students will choose those universities with higher recognition.

Therefore, in the new university environment students exert a higher competitive pressure on universities which have to try to attract students in order to guarantee their survival. In the questionnaires, Spanish students highlighted that universities should pay attention to work place requirements when they design syllabuses and also the development of skills must be an explicit goal of university education. In the opinion of the most of students, the development of skills should be integrated into the business administration and accounting units because it is possible to develop simultaneously technical knowledge and skills. Due to the lack of training in skills, among other things, students think that university studies are not preparing them for real world work. . In the students' opinion, the current contents of business administration and accounting units do not prepare them for doing well in the jobs which they may subsequently occupy.

Like professionals, students pointed out in the questionnaires several perceived limitations affecting the development of their skills. The first three limitations are: (1) the lack of collaboration between business organisations and universities, (2) the large class sizes in Spanish universities, and (3) the lack of economic and technical resources. Also, students highlighted limitations to the development of skills related to syllabuses (e.g. there are useless 
Gonzalez, J. M., Arquero, J. L., \& Hassall, T. (2009). Pressures and resistance to the introduction of skills in business administration and accounting education in Spain: a new institutional theory analysis. Journal of Vocational Education and Training, 61(1), 85-102.

Final paper available at http://www.tandfonline.com/doi/abs/10.1080/13636820902820071\#.VmfzkF5gvNI

units, the lack of significant labour experience during the training process), to educators (e.g. the lack of training of educators about the most effective way to teach students, the lack of interest of educators), and to students (e.g. the lack of relations between educators and students, the objective is to pass the exams instead of learning).

\section{Strategic response by Spanish universities}

University teachers, who constitute one of the most important stakeholders in the Spanish university system, have confirmed the importance of the development of skills for students. However, they admitted in the questionnaires and interviews they have not developed these skills in business administration and accounting units. In the questionnaires, the most of teachers highlighted that they should pay attention to work place requirements when they design syllabuses and also that the development of skills must be an explicit goal of university education. They pointed out that in their opinion it is possible to develop simultaneously skills and technical knowledge and reiterated the necessity to develop those skills in business administration and accounting units. These results were confirmed in the interviews. In this respect, it is representative the next comment of a interviewee: "in the current environment, technical knowledge is not enough. Other skills, such as teamwork, communication, participation, leadership, critical analysis are also very important to develop a job. For this reason, the development of these skills should be part of education plans of universities".

However, university accounting teachers also highlighted in the questionnaires several limitations in developing those skills, mainly: (1) the large class sizes in Spanish universities, (2) the lack of training of accounting educators about the development of skills which is the responsibility of the university institutions, and (3) the lack of practical experience of 
Gonzalez, J. M., Arquero, J. L., \& Hassall, T. (2009). Pressures and resistance to the introduction of skills in business administration and accounting education in Spain: a new institutional theory analysis. Journal of Vocational Education and Training, 61(1), 85-102.

Final paper available at http://www.tandfonline.com/doi/abs/10.1080/13636820902820071\#.VmfzkF5gvNI

accounting educators because of among other things, the lack of incentives and the difficulty of their integration in business organisations.

So, the results of the study evidence that university teachers have admitted the necessity of conformity to the pressures of the environment. They have not changed the nature of those pressures, but they have avoided that conformity because they have not developed the skills of students. Therefore, the study evidences that Spanish universities have followed an "avoidance" strategic response to the institutional and competitive pressures of their environment (Oliver, 1991). According to Etherington and Richardson (1994), "avoidance" has been an active and negative strategy in the studied case because respectively, the behaviours of teachers have differed from the requirements demanded by pressures of the environment and the conflict between behaviours and requirements have been maintained.

In order to go deeply into behaviours of teachers the tactics for each strategic response that were identified by Oliver (1991) can be considered. Specifically, this author identified three types of tactics into the "avoidance" strategy: (1) the "concealment" tactic which "involves disguising nonconformity behind a facade of acquiescence" (p. 154); (2) the "buffering" tactic which "refers to an organisation's attempt to reduce the extent to which it is externally inspected or evaluated" (p.155); and (3) the "escaping" tactic when an organisation exits the domain within which the pressures are exerted. In this respect, the teachers interviewed noted that pressures of the environment for developing skills would imply a higher dedication to the teaching duties and a lower dedication to their research activity. In order to gain promotion and to get a permanent job in university (tenure) the research activity of teachers is more important than the teaching duties and, therefore, teachers are more likely to be involved in research activities. As an interviewee noted, "we must be practical people and now the most important thing for us is to research in order to get the accreditations and to promote". Also, 
Gonzalez, J. M., Arquero, J. L., \& Hassall, T. (2009). Pressures and resistance to the introduction of skills in business administration and accounting education in Spain: a new institutional theory analysis. Journal of Vocational Education and Training, 61(1), 85-102.

Final paper available at http://www.tandfonline.com/doi/abs/10.1080/13636820902820071\#.VmfzkF5gvNI

if we analyse the norms about the assessment system of teachers (mainly the University Organic Law 6/2001 and the RD 1052/2002 concerning the accreditation process of teachers), we can realize that system assumes that the teaching duties are "well done" by teachers and these teaching duties are assessed exclusively according to the seniority of teachers.

Interviewees noted also that teachers tend to repeat the same behaviours that they learned from their previous teachers and they show resistance to the introduction of innovations, because these innovations entail cost for them. Thus, for instance, in developing skills interviewees commented that teachers should prepare new syllabuses, design new coursework for students, design new assessment systems and attend to training courses. As mentioned above, these activities of teachers are not valued in their promotion and, therefore, they are not motivated to engage with them.

Our results evidence that the tactic followed by Spanish universities has been "concealment" because teachers admit the necessity of introducing skills in the student's learning but they are reluctant to its introduction because this implies an increase in their work which is not taken into account for their assessment and promotion.

Because the new University Organic Law makes it compulsory to adapt to the EHEA in 2010 and this date is getting closer, it is causing a change in the strategic response of Spanish universities. Thus, since the academic year 2007/2008, we have observed that some Spanish universities are developing pilot projects for the introduction of ECTS in the degrees of Licenciado in Management and Business Administration and Diplomado in Business Studies. Also, Spanish teachers are exacting from the Spanish government some concessions for developing skills of students. Thus, the most of interviewees ask the Spanish government these concessions: a higher recognition of teaching duties because they are going to require a higher dedication from teachers; to modify the current assessment system of teaching duties 
Gonzalez, J. M., Arquero, J. L., \& Hassall, T. (2009). Pressures and resistance to the introduction of skills in business administration and accounting education in Spain: a new institutional theory analysis. Journal of Vocational Education and Training, 61(1), 85-102.

Final paper available at http://www.tandfonline.com/doi/abs/10.1080/13636820902820071\#.VmfzkF5gvNI

because it is exclusively based on the seniority of teachers; to introduce changes in the university infrastructure (e.g. more economic and technical resources, smaller classrooms and student groups); a higher involvement of professional accounting bodies in the design of the curriculum of students; and better staff training courses for developing skills. In this respect, some of these concessions (in particular, the change of the assessment system of teachers and changes in the university infrastructure) have been the cause of several organized demonstrations of university teachers in many regions of Spain during the second mid-2000s. Therefore, in the next years, Spanish universities have to compulsorily implement the ECTS which entails the development of skills and as a consequence they are beginning to adopt a "compromise" strategic response. Specifically from the three "compromise" tactics that Oliver (1991) identified (balancing, pacifying and bargaining tactics), Spanish universities are following the "bargaining" tactic which involves an effort to exact some concessions from an external constituent (specifically the Spanish government) in its demands.

\section{Institutional antecedents}

This section analyzes the antecedents of the "avoidance" strategy that has been followed by Spanish universities to respond to pressures of their environment (see Table 2).

\section{Cause (legitimacy - efficiency)}

The Spanish university system has constituted a stable institutional domain since the beginning of 1980s. In the opinion of the most of interviewees, Spanish universities traditionally have perceived that the development of skills was not necessary to increase their social fitness (legitimacy) or economic fitness (efficiency). In this sense, the legitimacy and efficiency have been traditionally achieved by universities through the fitness of their 
Gonzalez, J. M., Arquero, J. L., \& Hassall, T. (2009). Pressures and resistance to the introduction of skills in business administration and accounting education in Spain: a new institutional theory analysis. Journal of Vocational Education and Training, 61(1), 85-102.

Final paper available at http://www.tandfonline.com/doi/abs/10.1080/13636820902820071\#.VmfzkF5gvNI

education plans to the general guidelines (common and specific) that were set up by the Spanish government. A review of those guidelines (Royal Decree 1497/1987 and Royal Decree 1421/1990) reveals that there is not any norm about the development of skills.

\section{Constituents (multiplicity - resource dependence)}

The results of the questionnaires and the interviews as well as the review of the regulation of Spanish universities, which have been mentioned along the previous section, evidence that the external actors who are exerting pressure on Spanish universities (European Union, Spanish government, professionals and students) show a high degree of consensus in their demands being made to develop skills. All of them agree the necessity of the introduction of this change in higher education. However, the funding of Spanish universities comes mainly from the central and regional governments who have been very lax in the introduction of changes until the mid-2000s, like the most of interviewees noted. Also professionals and students did not have enough authority upon universities to press them to introduce the change. According to Modell (2005), the actors need to mobilize power for introducing a change; in our case, they did not get to mobilize the needed power to introduce the development of skills in the curriculum.

\section{Content (goal congruence - reduced discretion)}

The external actors require Spanish universities to provide a higher training not only in technical knowledge but also in skills which has a high degree of consistency with one of the main goals of universities: the education of their students. In respect of the antecedent "reduced discretion" it can be highlighted that, as we commented in the previous section, the introduction of skills in the education plans entails a greater dedication from accounting 
Gonzalez, J. M., Arquero, J. L., \& Hassall, T. (2009). Pressures and resistance to the introduction of skills in business administration and accounting education in Spain: a new institutional theory analysis. Journal of Vocational Education and Training, 61(1), 85-102.

Final paper available at http://www.tandfonline.com/doi/abs/10.1080/13636820902820071\#.VmfzkF5gvNI

teachers to teaching duties at the cost of a reduction of their research activity. Because of the low valuation of the teaching duties in the current promotion system accounting teachers generally resist pressures that increase their teaching duties.

\section{Control (coercion - diffusion)}

The Bologna Declaration was signed by the European Union countries in 1999 and the new University Organic Law came into effect in 2001. Nevertheless, the period for the implementation of the EHEA and the ECTS was delayed (until 2010) and therefore the obligation of implementing the change was not immediate. The interviewees highlighted that this fact contributed to the relaxed approach of Spanish universities and teachers in the development of skills that are required by the ECTS. Also, they noted that the voluntary dissemination of innovation is low because it is difficult to introduce changes. We can understand that this is due to the fact that Spanish universities constitute a very institutionalized organisational field (DiMaggio and Powell, 1991) and as a consequence their members have tended to adapt to the status quo instead of introducing changes.

\section{Context (interconnectedness - uncertainty)}

In respect of interconnectedness, the most significant aspect is that the participation of professionals in the design of accounting education plans is almost non-existent which is due to two main reasons: firstly, the education plans are often the result of a political negotiation; and secondly, professionals do not receive any motivation or incentive from universities. As an interviewee noted, "When universities prepare syllabuses, they do not encourage the involvement of professionals. This is because there is a power-sharing among departments of the universities and they don't want the participation of external agents". This lack of 
Gonzalez, J. M., Arquero, J. L., \& Hassall, T. (2009). Pressures and resistance to the introduction of skills in business administration and accounting education in Spain: a new institutional theory analysis. Journal of Vocational Education and Training, 61(1), 85-102.

Final paper available at http://www.tandfonline.com/doi/abs/10.1080/13636820902820071\#.VmfzkF5gvNI

participation of professionals is one of the main reasons of the gap between the current curriculum content of students in Management and Business Administration and the requirements demanded by professionals (Arquero et al., 2005). Spanish universities recognize the necessity of developing skills for reducing that gap. The implementation of ECTS, which is compulsory for universities, entails the development of skills in higher education. However, there is a great uncertainty about the best way to carry out the change because this means a new teaching and assessment approach.

\section{From the "avoidance" to "compromise" strategy: change in antecedents}

Since 2005 a change in the strategic response of Spanish universities in order to respond to the pressures of the environment can be identified: from the "avoidance" strategy to "compromise" strategy. As the implementation of the EHEA is getting closer (and therefore the introduction of the ECTS and the development of skills) some institutional antecedents are changing. These changes are causing the modification in strategy (Oliver, 1991; Etherington and Richardson, 1994). As most of the interviewees noted, universities are going to start competing among themselves in order to attract students. The successful universities will be those providing students with the knowledge and skills demanded by stakeholders. Also, the greater competition among universities will increase the dependence of universities on students. So, this change will require to universities a higher efficiency to satisfy the needs of students and therefore to guarantee their survival. Similarly universities will increase their social gain (legitimacy) by adapting to the changes demanded by external constituents, in particular the Spanish government, for the implementation of the EHEA.

As the implementation of the EHEA is getting closer, the coercion exerted by the Spanish government is increasing. Also, the professionals will have a higher responsibility for 
Gonzalez, J. M., Arquero, J. L., \& Hassall, T. (2009). Pressures and resistance to the introduction of skills in business administration and accounting education in Spain: a new institutional theory analysis. Journal of Vocational Education and Training, 61(1), 85-102.

Final paper available at http://www.tandfonline.com/doi/abs/10.1080/13636820902820071\#.VmfzkF5gvNI

designing the education plans because this is a measure demanded by the National Agency of Assessment of the University Quality and Accreditation (ANECA). This fact implies that the interconnectedness will be higher in the new higher education system. Finally, the introduction of changes derived from the implementation of EHEA in Spain is causing a turbulent environment in which Spanish universities have to operate under a higher uncertainty.

\section{Conclusions, implications and future research}

In Spain, there is a consensus among accounting professionals, students and teachers about the necessity of a broader education of students that includes not only the learning of technical knowledge but also the development of skills such as intellectual, interpersonal and personal skills. The introduction of these skills has not taken place yet in most Spanish universities where the students can undertake the degrees of Licenciado in Management and Business Administration and Diplomado in Business Studies. For this reason the paper has analysed the various sources of pressure for the development of skills into the business administration and accounting curriculum, the responses (or resistance strategies) of Spanish universities, that are delaying or hindering the implementation of that change, as well as the institutional characteristics of the environment that are determining those responses. Institutional theory has provided us a very valuable theoretical framework for developing this analysis.

The results of our study have made clear that there are both competitive and institutional (coercive, mimetic, normative) pressures on the Spanish university system for the introduction of skills into business administration and accounting curriculum. However, the institutional characteristics (which are grouped as cause, constituents, content, control and 
Gonzalez, J. M., Arquero, J. L., \& Hassall, T. (2009). Pressures and resistance to the introduction of skills in business administration and accounting education in Spain: a new institutional theory analysis. Journal of Vocational Education and Training, 61(1), 85-102.

Final paper available at http://www.tandfonline.com/doi/abs/10.1080/13636820902820071\#.VmfzkF5gvNI

context) have caused the Spanish universities to have carried out, until approximately 2005, an "avoidance" strategy. This has precluded the necessity of conformity without affecting the nature of pressures to change. Nevertheless, the institutional characteristics have changed since 2005, mainly because of the obligation for Spain to converge towards the EHEA. This has caused the Spanish universities to have adopted a "compromise" approach which implies the negotiation of a balance between the interests of universities and the pressures of the environment.

This research paper highlights the importance of analysing the institutional environment in which the change of education takes place since the characteristics of the environment can facilitate the change but also they can constrain it. Also, the analysis of the institutional environment is necessary to understand the responses of university systems to the pressures to change. In particular, as the institutional characteristics in the countries are usually different, it can highlight two important implications: (1) although the institutional pressures to change can be similar in the various countries their university systems can respond in a different way; and (2) although the various countries can try to implement the same change the use of "recipes" or common patterns for implementing the change are not appropriate due to the fact that the different characteristics of their institutional environments can upset the desired results.

From a NIS perspective, the implementation of the EHEA and its consequences on education constitute an interesting issue for future research. The EHEA is compulsory for the countries of the European Union who signed the Bologna Declaration. This change can have important consequences on business administration and accounting education in those countries. So, for instance, it could be interesting to analyse the deinstitutionalization process of the previous teaching methodologies and the institutionalization process of the new teaching 
Gonzalez, J. M., Arquero, J. L., \& Hassall, T. (2009). Pressures and resistance to the introduction of skills in business administration and accounting education in Spain: a new institutional theory analysis. Journal of Vocational Education and Training, 61(1), 85-102.

Final paper available at http://www.tandfonline.com/doi/abs/10.1080/13636820902820071\#.VmfzkF5gvNI

methodologies in the various countries. Further research is also necessary to increase our understanding about the influence of institutional characteristics of environments on the strategies adopted by universities to face the institutional pressures. Likewise further research could evidence whether the EHEA is implemented in an effective way, in order to increase the efficiency of the students learning; or it is implemented to maintain appearances by taking precedence of legitimacy over efficiency. The most appropriate research method would be a longitudinal case study, because it allows an in-depth study of the evolution of this type of phenomena which are characterized by their complexity.

\section{References}

Albrecht, W.S. and Sack, R.J. 2000. Accounting education: charting the course through a perilous future. Accounting Education Series, 16 (American Accounting Association).

American Accounting Association. 1986. Future of accounting education: preparation for the expanding profession. Issues in Accounting Education I, no. 1: 169-195.

American Institute of Certified Public Accountants. 1988. Education requirements for entry into the accounting profession (Revision of the Albers Committee Report). New York: AICPA.

Arquero, J.L. 2000. Capacidades no técnicas en el perfil profesional en contabilidad: las opiniones de docentes y profesionales. Revista Española de Financiación y Contabilidad XXIX, no. 103: 149-172.

Arquero, J.L. (Dir.) et al. 2005. Objetivos de formación en administración ante el EEES: especial referencia al área de economía financiera $y$ contabilidad. Córdoba: Unidad para la Calidad de las Universidades Andaluzas (UCUA).

Arquero, J.L. and Donoso, J.A. 2002. Lo importante son los números, ¿no? Las opiniones de los estudiantes Españoles de contabilidad sobre las capacidades no técnicas. Partida Doble, 132: 98-105.

Arthur Andersen \& Co. 1989. Perspectives on education: capabilities for success in the accounting profession. New York. 
Gonzalez, J. M., Arquero, J. L., \& Hassall, T. (2009). Pressures and resistance to the introduction of skills in business administration and accounting education in Spain: a new institutional theory analysis. Journal of Vocational Education and Training, 61(1), 85-102.

Final paper available at http://www.tandfonline.com/doi/abs/10.1080/13636820902820071\#.VmfzkF5gvNI

Asonitou, S. and Hassall, T. 2008. Resistance to change in accounting education: a Greek perspective. Paper presented at BAA Accounting Education SIG Annual Conference, May 19-21, in Seville (Spain).

Bosenbaum, E. and Jonsson, S. 2008. Isomorphism, diffusion and decoupling. In Organizational Institutionalism, eds. Royston Greenwood et al., 78-98. London: Sage Publications.

Brignall, S. and Modell, S. 2000. An institutional perspective on performance measurement and management in the new public sector. Management Accounting Research 11, no. 3: 281-306.

Carpenter, V.L. and Feroz, H.E. 2001. Institutional theory and accounting rule choice: an analysis of four U.S. state governments decisions to adopt generally accepted accounting principles. Accounting, Organizations and Society 26, no. 7-8: 565-596.

Carruthers, B.G. 1995. Accounting, ambiguity, and the new institutionalism. Accounting, Organizations and Society 20, no. 4: 313-328.

Dacin, M.T. 1997. Isomorphism in context: the power and prescription of institutional norms. Academy of Management Journal 40, no. 1: 46-81.

Dacin, M.T., Goodstein, J. and Scott, W.R. 2002. Institutional theory and institutional change: introduction to the special research forum. Academy of Management Journal 45, no. 1, 45-57.

Deephouse, D.L. 1996. Does isomorphism legitimate?. Academy of Management Journal 39, no. 4: 1024-1039.

Deephouse, D.L. and Suchman, M. 2008. Legitimacy in organizational institutionalism. In Organizational Institutionalism, eds. Royston Greenwood et al., 49-77. London: Sage Publications.

DiMaggio, P.J. and Powell, W.W. 1983. The iron cage revisited: institutional isomorphism and collective rationality in organizational fields. American Sociological Review 48: 147-160.

DiMaggio, P.J. and Powell W.W. 1991. The new institutionalism in organizational analysis. Chicago: University of Chicago Press.

Etherington, L.D. and Richardson, A.J. 1994. Institutional pressures on university accounting education in Canada. Contemporary Accounting Research, special education research issue: $141-162$. 
Gonzalez, J. M., Arquero, J. L., \& Hassall, T. (2009). Pressures and resistance to the introduction of skills in business administration and accounting education in Spain: a new institutional theory analysis. Journal of Vocational Education and Training, 61(1), 85-102.

Final paper available at http://www.tandfonline.com/doi/abs/10.1080/13636820902820071\#.VmfzkF5gvNI

Gammie, B. and Gammie, E. 2002. The impact of policy on professional practice in the university sector. The International Journal of Management Education 2, no. 2: 3-13.

González, J.M., Arquero, J.L. and Hassall, T. 2006. Los sistemas universitarios de Reino Unido y España ante el Espacio Europeo de Educación Superior: un estudio comparativo con especial referencia a la enseñanza de la contabilidad. Revista de Enseñanza Universitaria, no. 28: 19-33.

Greenwood, R., Suddaby, R. and Hinings, C.R. 2002. Theorizing change: the role of professional associations in the transformation of institutionalized fields. Academy of Management Journal 45, no. 1: 58-80.

Hassall, T., Joyce, J., Arquero, J.L. and Donoso, J.A. 2005. Priorities for the development of vocational skills in Management Accountants: an European perspective. Accounting Forum, 29: 379-394.

IFAC. 2003. International Education Standard 3. Professional Skills. International Education Standards for Professional Accountants. International Accounting Education Standards Board.

IFAC. 2006. International Education Standard 8. Competence Requirements for Audit Professionals. International Accounting Education Standards Board.

Langa, D. and David, M. 2006. A massive university or a university for the masses? Continuity and change in higher education in Spain and England. Journal of Education Policy 21, no. 3: 343-365.

Lounsbury, M. 2008. Institutional rationality and practice variation: new directions in the institutional analysis of practice. Accounting, Organizations and Society 33, no. 4/5: 349-361.

Meyer, H.D. and Rowan, B. 2006. The new institutionalism in education. New York: State University of New York Press.

Meyer, J.W. 1986. Social environments and organizational accounting. Accounting, Organizations and Society 11, no. 4-5: 345-356.

Meyer, J.W. and Rowan, B. 1977. Institutionalized organizations: formal structure as myth and ceremony. American Journal of Sociology 83, no. 2: 340-363.

Meyer, J.W. and Scott, R. 1982. Centralization and legitimacy problems of local government. In Organizational environments: ritual and rationality. Beverly Hills, CA: Sage Publications. 
Gonzalez, J. M., Arquero, J. L., \& Hassall, T. (2009). Pressures and resistance to the introduction of skills in business administration and accounting education in Spain: a new institutional theory analysis. Journal of Vocational Education and Training, 61(1), 85-102.

Final paper available at http://www.tandfonline.com/doi/abs/10.1080/13636820902820071\#.VmfzkF5gvNI

Mizruchi, M.S. and Fein, L.C. 1999. The social constitution of organizational knowledge: a study of the uses of coercive, mimetic and normative isomorphism. Administrative Science Quarterly 44, no. 4: 653-683.

Modell, S. 2005. Students as consumers? An institutional field-level analysis of the construction of performance measurement practices. Accounting, Auditing \& Accountability Journal 18, no. 4: 537-563.

Mora, J.G. 1999. Two decades of change in Spanish higher education. International Higher Education, Fall.

Mora, J.G., and Vidal, J. 2000. Changes in Spanish universities: improvements and unsolved conflicts. Planning for Higher Education 29, no. 2: 15-23.

Oliver, C. 1991. Strategic responses to institutional processes. Academy of Management Review 16, no. 1: 145-179.

Pfeffer, J. 1981. Power in organizations. Marshfieldm MA: Pitman.

Pfeffer, J. and Salancik, G. 1978. The external control of organizations: a resource dependence perspective. New York: Harper and Row.

Scott, R.W. 2001. Institutions and organizations. Foundations for organizational science. $2^{\text {nd }}$ Edition. Thousand Oaks, CA: Sage Publications.

Scott, R.W. and Meyer, J.W. 1994. Institutional environments and organizations. Thousand Oaks, CA: Sage Publications. 